\title{
Trophic state and seasonal dynamics of phytoplankton communities in two sand-pit lakes at different successional stages
}

\author{
Silvia TAVERNINI*, Daniele NIZZOLI, Giampaolo ROSSETTI and Pierluigi VIAROLI \\ Department of Environmental Sciences, University of Parma, Viale G.P. Usberti 11/A, 43100 Parma, Italy \\ *e-mail corresponding author: silvia.tavernini@nemo.unipr.it
}

\begin{abstract}
The seasonal and inter-annual dynamics of phytoplankton in two Italian sand-pit lakes have been analysed over three years (2004-2006). The studied lakes, Ca' Morta (CM) and Ca' Stanga (CS), have a common origin and are contiguous, but are of different ages and have been managed in different ways. CM was created in 2002 and was still being dredged during the study period, while sand quarrying in CS began in 1998 and ended at the beginning of the study period. These conditions were thought to be of particular interest in assessing the influence of dredging activities on algal assemblages. Physical and chemical water parameters were also analysed to characterise the two lakes and investigate the effects of hydro-chemical features on phytoplankton. CS was stratified from April to October each year during the study period, while CM showed weaker thermal stratification. Conductivity, dissolved nitrate and dissolved reactive silica concentrations were greater in CM than in CS. The mixing depth/euphotic depth ratio was also higher in CM, probably because of water column mixing induced by hydraulic dredging. Overall, 185 phytoplankton taxa were found, of which ca 50\% were present in both lakes. No significant differences in species richness were observed between lakes, but the decreasing trend of Simpson index values measured in CS showed a reduction in biodiversity after the excavation phase. Phytoplankton biomass was higher in CS than in CM, the latter being oligo-mesotrophic and the former mesotrophic. Diatoms and dinoflagellates were the dominant taxa in both lakes. The main differences in phytoplankton assemblages were related to the persistence of chryptophytes and chlorophytes in CM. Multivariate analyses support the hypothesis that different thermal patterns induced by dredging activities, along with certain physico-chemical parameters of the water, were the major factors shaping phytoplankton communities.
\end{abstract}

Key words: hydraulic dredging, species richness, phytoplankton biomass, thermal stratification

\section{INTRODUCTION}

In the last few decades, gravel- and sand-pit lakes have been created as a consequence of quarrying, especially in river floodplains (Garnier \& Billen 1994). They are generally isolated water-bodies that receive occasional surface runoff and are mainly fed by groundwater (Ejsmont-Karabin 1995). However, lakes located in the riverine transitional zones are often connected to rivers or channels, which greatly influence their hydrology and trophic status (Viaroli et al. 2002). Due to their location along the river margin, pit lakes could represent an opportunity for restoring lentic water bodies and wetlands, which have disappeared from the floodplains of many countries since the mid- $20^{\text {th }}$ Century due to heavy wetland reclamation, hydraulic regulation and a deterioration in environmental conditions (Viaroli et al. 1996).

To date, studies on phytoplankton communities in such lakes have consisted of strict taxonomic analyses of pit lakes located in Spain (Rojo \& Alvarez Cobelas 1992-1994; Asencio \& Aboal 2000), Italy (Salmaso et al. 1995; Genoni et al. 2003) and Central Europe (Hindák \& Hindáková 2003). Most of these studies were carried out at the end of the excavation phase, when lakes had became hydrologically mature, but little is known about trophic states and colonisation patterns during the excavation period. However, hydraulic dredging normally causes water turbulence, which tends to disrupt thermal stratification and enhances the resuspension of fine sediments, which are known to influence both the biomass and the seasonal dynamics of plankton communities (Agbeti et al. 1997; Alvarez-Cobelas et al. 2006; Burford \& O'Donohue 2006). It is likely that mechanical mixing depresses phytoplankton abundance when phytoplankton species are light-limited, although resuspended nutrients could also promote algal growth (Burford \& O'Donohue 2006). Mixing can determine the substitution of phytoplankton assemblages (NaselliFlores 2000). In shallow waters, turbulent mixing can also favour the resuspension of benthic forms, thus controlling benthic-pelagic coupling.

The rationale for this research is to provide new insight into factors controlling the build-up and development of phytoplankton communities in these poorly investigated ecosystems, stressing the effects of different management practices on algal assemblages. In this paper, we discuss the results of a three-year study on the phytoplankton communities of two Italian sand-pit lakes that have a common origin, display similar morphological features and are spatially contiguous, but differ in age and management regime. These ideal conditions allowed us to study the effects of dredging on the structure and succession of phytoplankton communities. 
The physical and chemical characteristics of the water column have been analysed to identify the possible impact of nutrient availability on algal assemblages in these artificial lakes.

\section{MATERIAL AND METHODS}

\subsection{Study area}

The study has been carried out in two neighbouring lakes $(2 \mathrm{~km}$ apart) created as a result of sand mining with hydraulic dredging (Tab. 1). The lakes are located in a highly populated area in Northern Italy, approximately $2 \mathrm{~km}$ from the main course of the Po River. Both lakes have no inlet or outlet connections to the river, and are mainly fed by groundwater from the same source. Quarrying of lake Ca' Stanga (CS) began in June 1998 and ceased in April 2004. In lake Ca' Morta (CM), sand mining began in February 2002 and operations are still ongoing at present. Sand extraction was performed daily for approximately 8 hours during working days. Dredging was taking place $c a 300 \mathrm{~m}$ from the sampling point.

Tab. 1. Geographical and morphometric features of lakes $\mathrm{Ca}^{\prime}$ Morta (CM) and Ca' Stanga (CS).

\begin{tabular}{lcc}
\hline & $\mathrm{CM}$ & $\mathrm{CS}$ \\
\hline Latitude N & $45^{\circ} 03^{\prime} 33^{\prime \prime}$ & $45^{\circ} 03^{\prime} 15^{\prime \prime}$ \\
Longitude E & $09^{\circ} 46^{\prime} 15^{\prime \prime}$ & $09^{\circ} 47^{\prime} 47^{\prime \prime}$ \\
Maximum lenght (m) & 633 & 423 \\
Maximum width (m) & 307 & 319 \\
Surface area $\left(\mathrm{m}^{2}\right)$ & 143,317 & 113,535 \\
Volume $\left(\mathrm{m}^{3}\right)$ & $1,358,595$ & $1,018,935$ \\
Maximum depth (m) & 17 & 17 \\
Mean depth (m) & 9.5 & 9.0 \\
Perimeter (m) & 1875 & 1441
\end{tabular}

\subsection{Water sampling and analytical methods}

Field measurements and the collection of water and biological samples were performed approximately at monthly intervals at the maximum depth stations in each lake, from January 2004 to December 2006. On each sampling date, temperature $(\mathrm{T}), \mathrm{pH}$, dissolved oxygen (DO) and specific conductivity at $25{ }^{\circ} \mathrm{C}$ (EC) were measured along the water column at $1 \mathrm{~m}$ depth intervals with a multi-parametric probe (YSI, 556 MPS model). Water transparency was measured via Secchi disk depth (SD). Water samples were collected from each lake at surface, $-1 \mathrm{~m},-2 \mathrm{~m},-4 \mathrm{~m},-6 \mathrm{~m},-8 \mathrm{~m},-12 \mathrm{~m}$ and $-16 \mathrm{~m}$ using a Ruttner bottle. Samples were stored at $4{ }^{\circ} \mathrm{C}$ until analysed (within 24 hours) for dissolved inorganic carbon (DIC), suspended particulate matter (SPM), dissolved organic phosphorus (DOP), soluble reactive phosphorus (SRP), nitrate $\left(\mathrm{NO}_{3}{ }^{-}\right)$, nitrite $\left(\mathrm{NO}_{2}{ }^{-}\right)$and ammonium $\left(\mathrm{NH}_{4}{ }^{+}\right)$, dissolved reactive silica (DRSi) and chlorophyll-a (Chl- $a)$, following standard methods (A.P.H.A. 1998). Total dissolved phosphorus (TDP) was defined as the sum of DOP and SRP. Total dissolved inorganic nitrogen (DIN) was defined as the sum of $\mathrm{NH}_{4}^{+}, \mathrm{NO}_{2}{ }^{-}$and $\mathrm{NO}_{3}^{-}$. Each year, the ionic composition of water sampled during the late winter turnover was analysed using Gran titration for $\mathrm{HCO}_{3}^{-}$, ion-chromatography (Dionex, DX 100) for $\mathrm{Cl}^{-}, \mathrm{SO}_{4}{ }^{2-}, \mathrm{NO}_{3}{ }^{-}$and plasma emission spectrophotometry with optical detection (ICP AES Philips Analyticals 7450) for $\mathrm{Mg}^{2+}, \mathrm{Na}^{+}$, $\mathrm{Ca}^{2+}, \mathrm{K}^{+}$.

\subsection{Phytoplankton sampling and counting}

Phytoplankton samples were collected monthly in 2004 and every two months in 2005 and 2006, following the same methodology used for water samples. Each phytoplankton sample was immediately fixed with Lugol's iodine solution. An integrated sample was subsequently obtained by combining equal proportions of samples collected at the various depths within the surface layers of each lake, namely $0 /-6 \mathrm{~m}$ in CS and $0 /-8 \mathrm{~m}$ in CM. Surface layers were chosen based on the mean depth of the thermocline in summer.

Phytoplankton were identified and counted with an inverted microscope according to Utermöhl (1931). Cell biovolume of each species was calculated by approximating the cell shapes to simple geometrical solids (Rott 1981; Hillebrand et al. 1999). Counts were made for both determinable and non-determinable fractions, the latter represented almost exclusively by ultraplankton (naked or flagellate cells of a maximum linear diameter of around $4 \mu \mathrm{m}$ ) and undetermined nanoplankton (both naked and flagellate, up to $8 \mu \mathrm{m}$ ). During enumeration, it was not possible to identify small centric diatoms to species level because of the limited magnifying power used $(200 \times$ and $400 \times)$. Cyclotella species were separated into two groups according to their dimensions (small Cyclotella with $\varnothing \leq 8 \mu \mathrm{m}$, large Cyclotella with $\varnothing$ $>8 \mu \mathrm{m}$ ). These diatoms were subsequently identified to species level after hydrogen peroxide digestion with the aid of a SEM. Species were identified according to Huber-Pestalozzi (1961, 1969), Huber-Pestalozzi \& Fott (1968), Fott (1972), Førster (1982), Komarek \& Fott (1983) and Bourelly $(1981,1985,1990)$, although major groups were identified based on other specific keys, i.e., Krammer \& Lange-Bertalot (1991a-b, 1997a-b) for diatoms, Komárek \& Anagnostidis $(1999,2005)$ and Anagnostidis \& Komarek (2005) for cyanophytes and Popovskì \& Pfiester (1990) for dinoflagellates.

\subsection{Data analysis}

The stability of the water column was estimated based on the square of the Brunt Väisälä frequency, or buoyancy frequency $\left(\mathrm{N}^{2}\right)$, using temperature profiles as an analogue of stability (Reynolds \& Bellinger 1992).

The mixing depth/euphotic depth ratio $\left(\mathrm{z}_{\mathrm{mix}} / \mathrm{z}_{\mathrm{eu}}\right)$ was calculated because this parameter is useful in describing the underwater light climate of a given water body (Naselli Flores \& Barone 2007). Mixing depth was estimated from temperature profiles. It was considered to be equal to the depth where the difference in tem- 
perature between contiguous layers was highest. Following Scheffer (1998), the euphotic depth was estimated as 1.7 times the Secchi disk depth.

Differences between the lakes as regards physicochemical features, $\mathrm{N}^{2}$ and phytoplankton biomass were tested via the Kolmogorov-Smirnov test (Sokal \& Rohlf 1995).

The Margalef index (d) and Simpson index (1-D, evenness index) were calculated based on density data for each lake on each sampling date.

The relationships between phytoplankton species and physico-chemical variables were assessed through multivariate analyses. Phytoplankton taxa were included in the analyses only when their overall biovolume was greater than $1 \mathrm{mg} \mathrm{m}^{-3}$ in the three years. Taxa of the same genus or group which exhibited similar temporal patterns and which had similar ecological characteristics according to the literature mentioned in the previous paragraph were combined, namely: Snowella atomus Cyanogranis ferrugginea; Cryptomonas erosa - $C$. erosa v. reflexa, centric diatoms, and species of the genus Carteria; Cymbella; Fragilaria; Gymnodinium; Mallomonas; Mougeotia; Navicula; Oocystis and Oscillatoria (for a list of phytoplanktonic taxa included in the analysis, see figure 6B caption). In the end, 93 phytoplanktonic taxa were taken into consideration.

First, a detrended correspondence analysis (DCA) of the phytoplankton species data, with species data log $(\mathrm{x}+1)$ transformed and rare taxa downweighted, was used to determine whether linear or unimodal ordination methods should be applied (Ter Braak \& Šmilauer 2002). The length of axes resulting from DCA provides a measurement of the total heterogeneity in the phytoplankton community. Because the length of the first axis was less than 3.0 (Ter Braak \& Prentice 1998), a linear method (Redundancy Analysis, RDA) was chosen. Of the physical and chemical variables, EC, $\mathrm{pH}, \mathrm{DIC}, \mathrm{DIN}$, TDP and DRSi were chosen for the analysis after checking for autocorrelation. $\mathrm{N}^{2}$ and $\mathrm{z}_{\mathrm{mix}} / \mathrm{z}_{\mathrm{eu}}$ were also included to assess the impact of dredging and underwater light climate on phytoplankton community structure. Lastly, to assess the impact of grazing pressure on phytoplankton assemblages, zooplankton densities (Zoo) were considered. Data on zooplankton are presented in Tavernini et al. (2009). In all, nine explanatory variables (EC, pH, DIC, DIN, TDP, DRSi, N ${ }^{2}, \mathrm{z}_{\text {mix }} / \mathrm{z}_{\mathrm{eu}}$ and Zoo) were used for the RDA. All the variables (except $\mathrm{pH})$ were $\log (\mathrm{x}+1)$ transformed prior to being analyzed. Three samples, collected in January 2004 in CM and CS and in December 2006 in CM, were excluded from the analyses because of missing hydrochemical data. To determine the subset of variables that best explained phytoplankton distribution in the lakes studied, a series of RDAs constrained to individual variables was first run. This process produces a $\mathrm{P}$ value, a constrained eigenvalue $\left(\lambda_{1}\right)$, and an unconstrained eigenvalue $\left(\lambda_{2}\right)$. The $\lambda_{1} / \lambda_{2}$ ratio represents the relative strength of each variable in explaining variance in the species data. Of eight variables, $\mathrm{N}^{2}, \mathrm{EC}$, DIC and DRSi were found to be significant $(p<0.05)$. Thus, partial RDAs were performed to separate the effects of the four explanatory variables on phytoplankton distribution. The first partial analysis used $\mathrm{N}^{2}$ as an explanatory variable and EC, DIC and DRSi as covariables to estimate the pure effects of various degrees of stratification on algal assemblage. The second pRDA, with EC, DIC and DRSi as variables and $\mathrm{N}^{2}$ as covariable, explained the percentage of species variability that could only be accounted for by the ionic content of the water. Finally, a RDA with the four variables used as explanatory variables was performed. The significance of the ordination axes was always tested via Monte Carlo permutation tests with 1000 random permutations $(p<0.05)$. Statistical analyses were performed using SPSS 13.0 for Windows (Release 13.0.0, (C) 2004, SPSS, Inc., Chicago, IL, U.S.A.), and CANOCO version 4.5 (Ter Braak \& Šmilauer 2002).

\section{RESULTS}

\subsection{Physical and chemical variables}

Both lakes were homothermal in winter $\left(4-5{ }^{\circ} \mathrm{C}\right)$ and thermally stratified in summer, with surface temperatures up to $29^{\circ} \mathrm{C}$ (Fig. 1). Thermal stability was weaker in $\mathrm{CM}$, where hypolimnion temperatures were between 11 and $16^{\circ} \mathrm{C}$ in the summer, while in CS the greater stratification kept hypolimnion temperatures considerably lower $\left(7-10^{\circ} \mathrm{C}\right)$. Accordingly, $\mathrm{N}^{2}$ resulted significantly lower in CM than in CS (Kolmogorov-Smirnov test, $p<0.05$ ) (Fig. 2). In CM, Secchi disk depth decreased throughout the study, with the lowest values measured at the end of 2006 (Fig. 2). In CS, seasonal trends in Secchi disk were evident, with spring minima coinciding with peaks in phytoplankton biomass (Fig. 2). Chl- $a$ concentrations (Tab. 2) were inversely related to Secchi disk depth in both $\mathrm{CM}(R=0.94, p<0.05)$ and CS $(R=0.95, p<0.05)$. In CS, the mean $\mathrm{z}_{\text {mix }} / \mathrm{z}_{\mathrm{eu}}$ ratio was $2.0 \pm 0.9 \mathrm{SD}$, with the highest values of 4.9 and 3.3 measured in January and February 2004. In CM, the mean $\mathrm{z}_{\text {mix }} / \mathrm{z}_{\text {eu }}$ ratio was $2.6 \pm 2.3 \mathrm{SD}$, with the highest values $(>5)$ recorded in late summer-autumn in all three years. SPM concentrations were higher in CM than in CS due to the higher values measured in the hypolimnion (Kolmogorov-Smirnov test, $p<0.05$ ) (Tab. 2).

The main chemical characteristics of the waters are summarised in tables 2 and 3. Considering the surface layer only, EC was relatively constant over the three sampling years in both basins, but EC values were significantly higher in CM than in CS (Kolmogorov-Smirnov test, $p<0.05)$, with a clear decrease during the summer months in both lakes (Fig. 2). The two lakes had similar ion concentrations. $\mathrm{Ca}^{2+}$ was dominant among cations and $\mathrm{HCO}_{3}{ }^{-}$among anions; DIC content and $\mathrm{pH}$ values had similar ranges. 


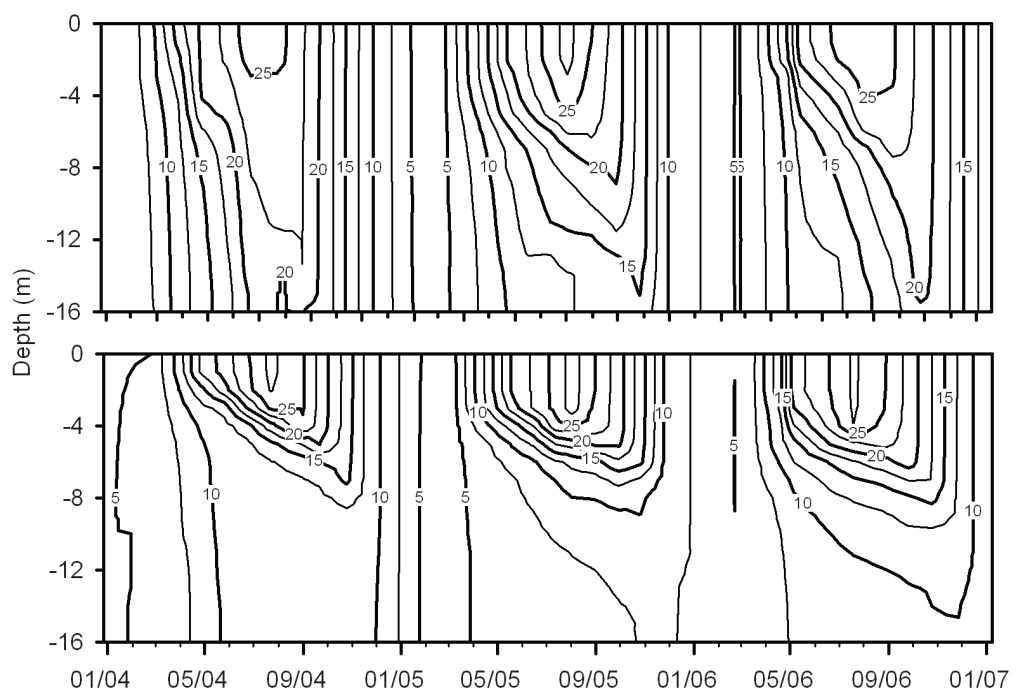

Fig. 1. Changes in temperature $\left({ }^{\circ} \mathrm{C}\right)$ with depth and time in $\mathrm{CM}$ (upper) and CS (lower) during the study period. Isopleths are based on $1 \mathrm{~m}$ interval measurements.

Tab. 2. Median, lowest (Min) and highest (Max) values of dissolved oxygen (DO), specific conductivity at $25{ }^{\circ} \mathrm{C}$ (EC), $\mathrm{pH}$, chlorophyll- $a$ (Chl- $a$ ), suspended particulate matter (SPM), dissolved inorganic carbon (DIC), ammonium $\left(\mathrm{NH}_{4}^{+}\right)$, nitrate $\left(\mathrm{NO}_{3}{ }^{-}\right)$, total dissolved phosphorus (TDP) and dissolved reactive silica (DRSi) in CM and CS during the study period. Whole lake: W, epilimnion: E, hypolimnion: $\mathrm{H}$.

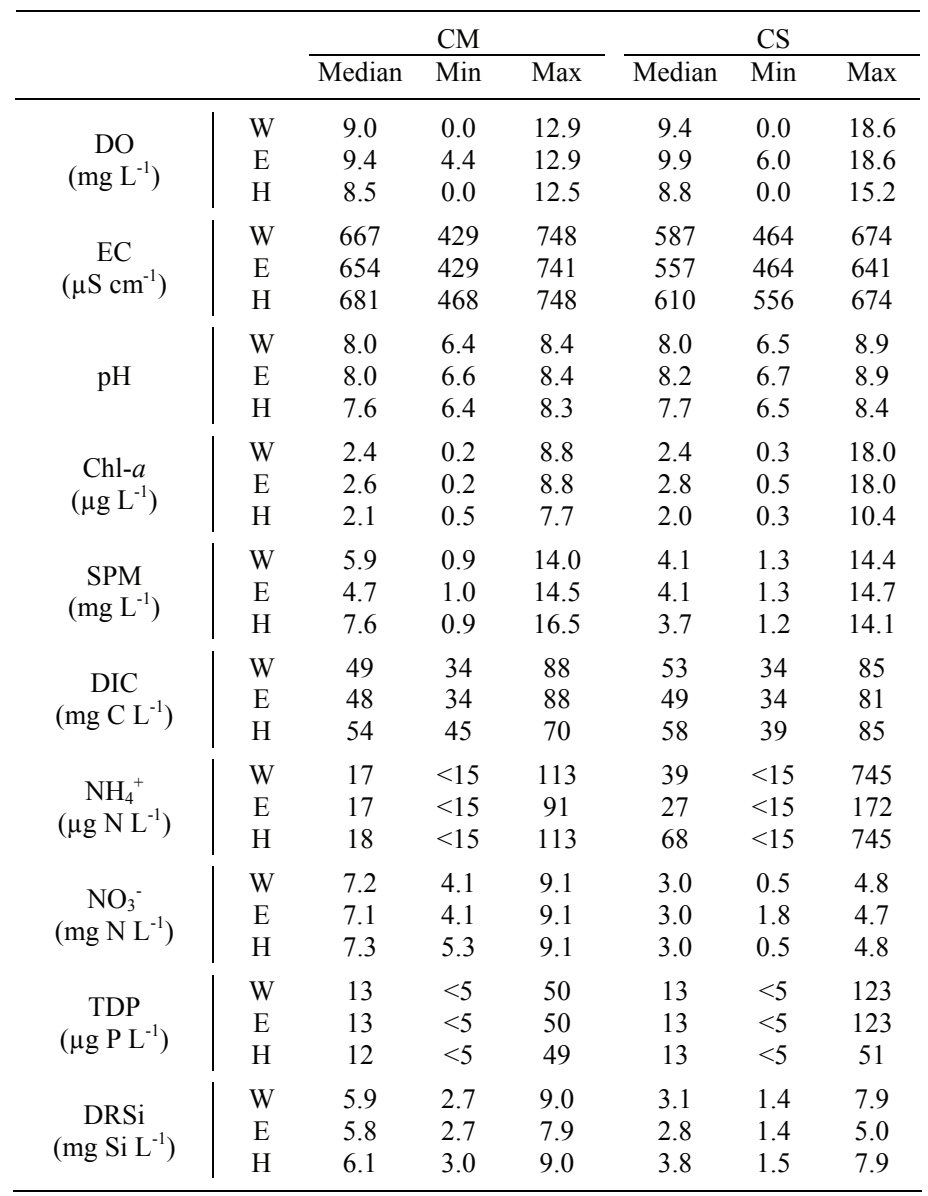



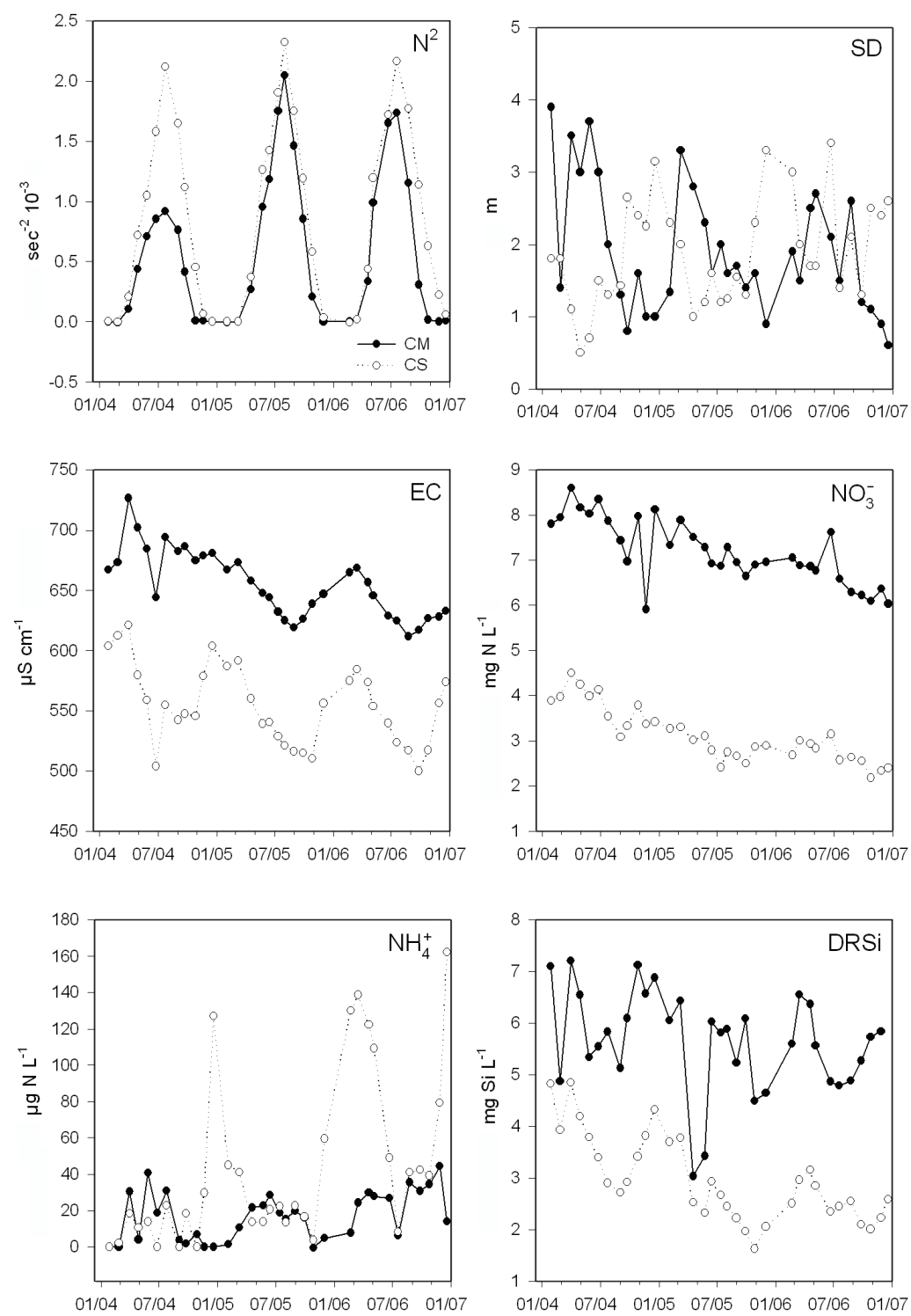

Fig. 2. Buoyancy frequency $\left(\mathrm{N}^{2}\right)$, Secchi disk depth (SD), conductivity (EC), nitrate $\left(\mathrm{NO}_{3}{ }^{-}\right)$, ammonium $\left(\mathrm{NH}_{4}^{+}\right)$and dissolved reactive silica (DRSi) in CM (full line) and CS (dotted line). Data of hydrochemical parameters represent weighted volume average value of $0-6 \mathrm{~m}$ in $\mathrm{CS}$ and $0-8$ in $\mathrm{CM}$.

Tab. 3. Ionic composition of lake waters in $\mathrm{CM}$ and CS during the spring late-winter turnover. Arithmetic mean \pm standard deviation $(\mathrm{N}=3)$ and percent contribution of each ion (in brackets) are reported.

\begin{tabular}{lcc}
\hline & $\mathrm{CM}$ & $\mathrm{CS}$ \\
\hline $\mathrm{Mg}^{2+}$ & $2.8 \pm 0.1(38 \%)$ & $2.6 \pm 0.1(40 \%)$ \\
$\mathrm{Na}^{+}$ & $0.6 \pm 0.0(8 \%)$ & $0.5 \pm 0.0(8 \%)$ \\
$\mathrm{Ca}^{2+}$ & $3.9 \pm 0.3(53 \%)$ & $3.2 \pm 0.3(51 \%)$ \\
$\mathrm{K}^{+}$ & $0.1 \pm 0.0(1 \%)$ & $0.1 \pm 0.0(1 \%)$ \\
$\sum$ cations & $7.3 \pm 0.3(100 \%)$ & $6.3 \pm 0.3(100 \%)$ \\
$\mathrm{HCO}_{3}{ }^{-}$ & $4.3 \pm 0.3(60 \%)$ & $4.4 \pm 0.2(69 \%)$ \\
$\mathrm{Cl}^{-}$ & $0.8 \pm 0.0(11 \%)$ & $0.4 \pm 0.0(6 \%)$ \\
$\mathrm{SO}_{4}{ }^{2-}$ & $1.5 \pm 0.1(21 \%)$ & $1.3 \pm 0.0(20 \%)$ \\
$\mathrm{NO}_{3}{ }^{-}$ & $0.5 \pm 0.1(8 \%)$ & $0.2 \pm 0.1(4 \%)$ \\
$\sum$ anions & $7.2 \pm 0.3(100 \%)$ & $6.3 \pm 0.3(100 \%)$ \\
\hline
\end{tabular}

During the three years of investigation, epilimnetic $\mathrm{Ca}^{2+}$ and $\mathrm{HCO}_{3}{ }^{-}$concentrations were higher in winter and declined through the summer in both lakes, while conservative ions (i.e., $\mathrm{Cl}^{-}$) remained relatively constant.

DIN and DRSi concentrations were significantly different between the two lakes (Kolmogorov-Smirnov test, both $p<0.05$ ) (Fig. 2). Nitrate constituted the largest fraction (up to $90 \%$ ) of DIN in both CM and CS. Higher concentrations were measured in CM (up to 8.6 $\mathrm{mg} \mathrm{N} \mathrm{L}{ }^{-1}$, March 2004) compared to CS (up to $4.5 \mathrm{mg} \mathrm{N}$ $\mathrm{L}^{-1}$, March 2004). In both lakes, $\mathrm{NO}_{3}^{-}$concentrations decreased between June 2004 and December 2006. In $\mathrm{CM}, \mathrm{NH}_{4}{ }^{+}$concentrations remained fairly constant over the sampling period and were generally $<40 \mu \mathrm{g} \mathrm{L}^{-1}$, while in CS ammonium showed clear peaks in late 

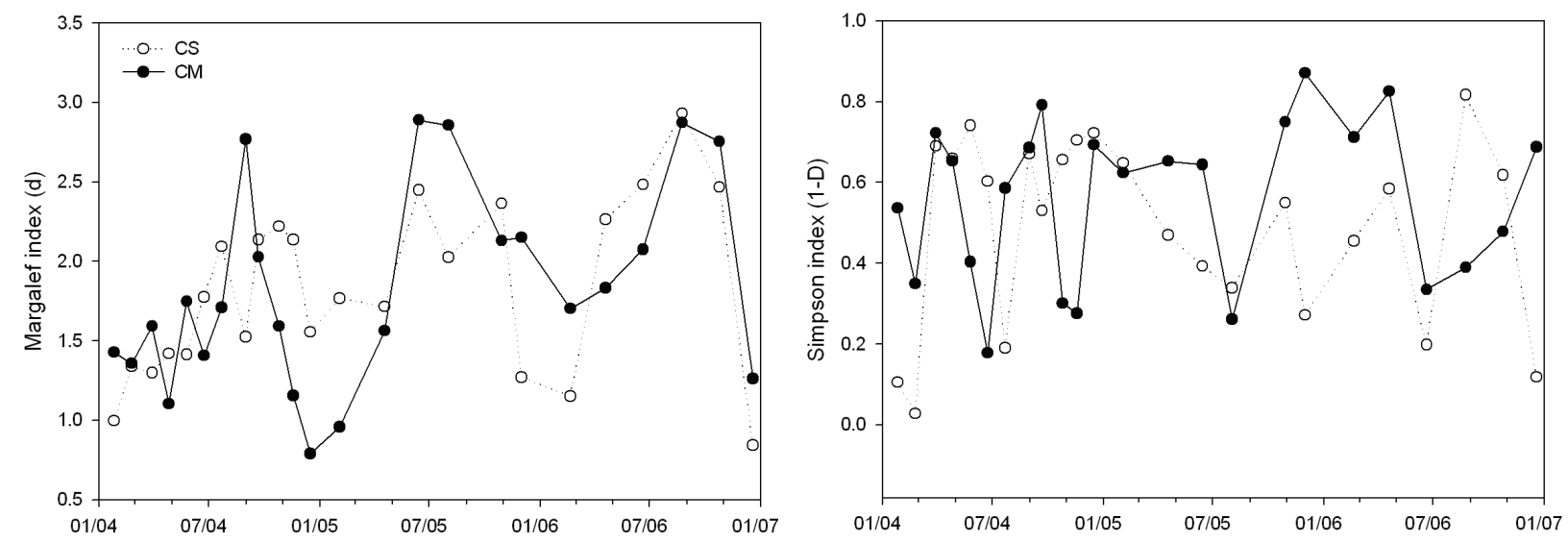

Fig. 3. Values of Margalef (d, right) and Simpson (1-D, left) indexes in CM (full line) and CS (dotted line).

winter with a progressive increase up to $160 \mu \mathrm{g} \mathrm{L} \mathrm{L}^{-1}$ in December 2006 (Fig. 2). DRSi values were higher in $\mathrm{CM}\left(5.7 \pm 0.9 \mathrm{mg} \mathrm{L}^{-1}\right)$ than in CS $\left(3.0 \pm 0.8 \mathrm{mg} \mathrm{L}^{-1}\right)$. In CS, DRSi concentrations decreased from January 2004 (4.8 $\left.\mathrm{mg} \mathrm{L}^{-1}\right)$ to December 2006 (2.5 $\left.\mathrm{mg} \mathrm{L}^{-1}\right)$. TDP concentrations were not significantly different between the two lakes and were relatively low (between 5 and $36 \mu \mathrm{g}$ $\left.\mathrm{P} \mathrm{L}^{-1}\right)$, except for one isolated sample collected in $\mathrm{CS}$ in July 2004, when the highest TDP value $\left(123 \mu \mathrm{g} \mathrm{P} \mathrm{L}^{-1}\right)$ was measured at surface (Tab. 2). Average SRP concentrations were low (below $5 \mu \mathrm{g} \mathrm{P} \mathrm{L}^{-1}$ ) in both lakes, without a clear seasonal pattern in the hypolimnion or in the epilimnion.

\subsection{Phytoplankton diversity}

Overall, 185 taxa were identified. 40 of these taxa were found exclusively in CM and 44 exclusively in CS, while 101 were found in both lakes. In CM, 87 taxa in total were found in 2004, and 29 and 25 new taxa were identified in the second and third year of study, respectively. In CS, 101 taxa in total were found in the first year, and 27 and 17 new taxa appeared in 2005 and 2006, respectively.

The largest number of organisms identified belonged to Chlorophyceae (63), Bacillariophyceae (50), Cyanophyceae (23), and Chrysophyceae (23). The number of chlorophytes was higher in CM (51) than in CS (42), whereas twice as many cyanophyte species were found in CS (22) than in CM (11). The most common species found in all samples from both lakes were the flagellates Cryptomonas erosa and Plagioselmis nannoplanctica. Small Cyclotella spp. were found in all the samples collected in CS and in 19 out of 24 samples collected in CM. Cryptomonas erosa and centric diatoms also contributed a large proportion of the total annual biovolume of both CM and CS (see below).

In $\mathrm{CM}$, the highest Margalef index values were reached in summer (i.e., 2.77 in August 2004, 2.88 in June 2005, 2.87 in August 2006), followed by a decreasing trend until December (Fig. 3). In CS the highest values were measured in October 2004 (2.22), June 2005 (2.44) and August 2006 (2.93) (Fig. 3). In both lakes, the lowest species richness was observed in winter-early spring. Until April 2005, the number of species found in each sample was generally higher in CS than in CM; subsequently, samples from both lakes had similar species richness, and some samples from $\mathrm{CM}$ were richer in species than samples from CS. The Simpson index in CM showed the lowest values in summer, when total community abundance was dominated by few species, while in winter species had similar densities (Fig. 3). This trend was less clear in CS, where the highest evenness was measured in 2004 (i.e., 0.77 in May, 0.74 in December) and again only in August 2007 (0.82) (Fig. 3).

\subsection{Seasonal and inter-annual phytoplankton dynamics}

Mean annual algal biomass was significantly lower in CM $\left(366 \pm 350 \mathrm{mg} \mathrm{m}^{-3}\right)$ than in CS $\left(658 \pm 504 \mathrm{mg} \mathrm{m}^{-3}\right)$ (Kolmogorov-Smirnov test, $p<0.05$ ), even though in 2006 the higher biomass peaks were measured in CM (Fig. 4). In both lakes, a positive relationship was observed between biomass and chlorophyll-a values, which was slightly weaker in CM (linear regression, $\log (\mathrm{x}+1)$ transformed data, $R=0.97, p=0.06)$ than in CS $(R=0.98, p<0.05)$. Differences in total biomass were mainly due to cryptophytes, diatoms and dinophytes (Kolmogorov-Smirnov test, all $p<0.05$ ) (Fig. 5). Diatoms and dinophytes were the dominant groups in both lakes, together with chrysophytes in CS and cryptophytes in CM.

In $\mathrm{CM}$, biomass paralleled the increase in species richness, with biomass peaks measured in summer each year (Fig. 4). Only cryptophytes - mainly C. erosa and $P$. nannoplanctica - were present throughout the study period, with the highest values measured in 2006 (Fig. 5 ). The greatest abundances of cryptophytes were observed during the periods with the lowest $\mathrm{N}^{2}$ values (Figs 2 and 5). Diatoms - mainly Centrales and occasionally Nitzschia acicularis and single-celled Fragi- 

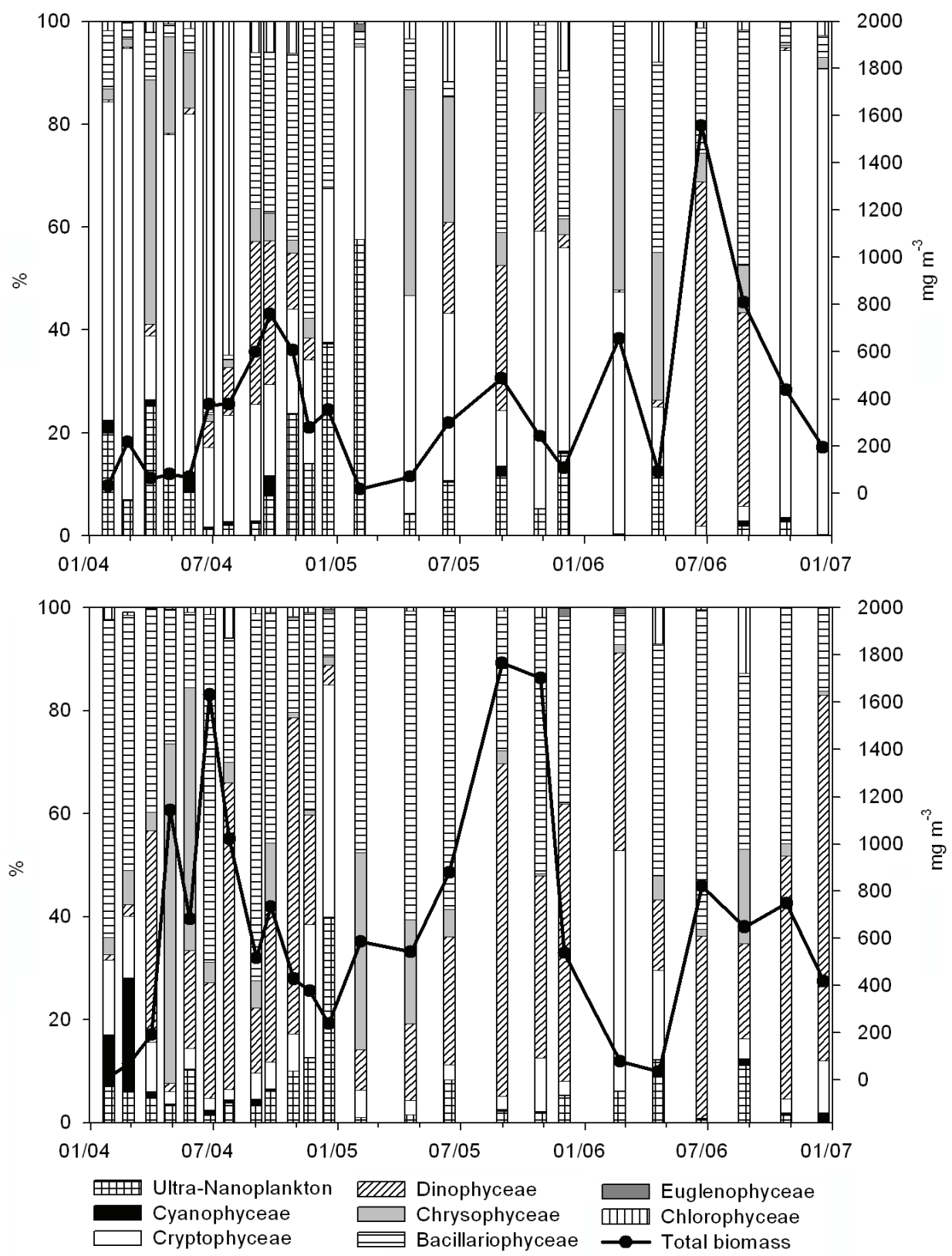

Fig. 4. Percentage composition of the phytoplankton, showing the occurrence of the eight main groups (vertical bar chart, left axis) and total biomass dynamics $\left(\mathrm{mg} \mathrm{m}^{-3}\right)$ (line and scatter plot, right axis) in CM (upper) and CS (lower).

laria sp. - attained a biomass bulk in the second half of the year, while dinoflagellates were present only in summer (Figs 5b and 5c). Chrysophytes showed increasingly higher biomass peaks throughout the study period (Fig. 5d). In June and July 2004, the chlorophytes Planctonema lauterbornii and Tetrachlorella incerta dominated the phytoplankton community, contributing up to $75 \%$ of the total biomass (Fig. 4).

In CS, biomass peaks occurred in summer and were sustained by centric diatoms (mainly Cyclotella spp. and occasionally Stephanodiscus alpinus and S. parvus) along with the dinoflagellate Ceratium hirudinella and some small Gymnodinium spp. Diatoms were always present, while dinoflagellates were normally observed only in summer (Figs 4 and 5), when the highest $\mathrm{N}^{2}$ values were measured (Figs 2 and 5). Chrysophytes made an important contribution to the total biovolumes, particularly in 2004 (Dinobryon sociale var. americana) and 2005 (D. divergens and Chrysolykos planctonicus), generally attaining their highest biomass in late winterearly spring (Figs 4 and 5).

\subsection{Multivariate analysis}

Backwards elimination in RDA identified four environmental variables (EC, DIC, DRSi and $\mathrm{N}^{2}$ ) that significantly $(p<0.05)$ explained variation in the phyto- 

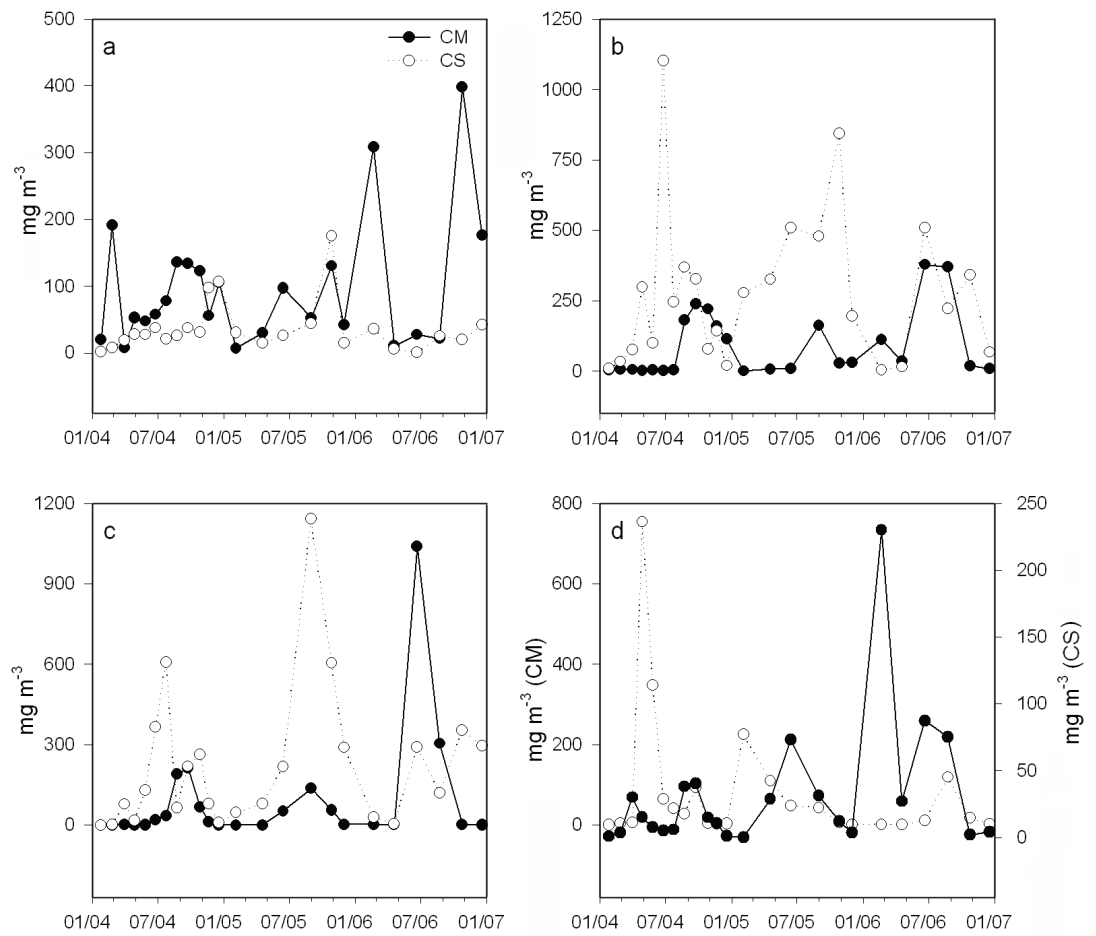

Fig. 5. Monthly biomass of Cryptophyceae (a), Bacillariophyceae (b), Dinophyceae (c) and Chrysophyceae (d) in CM (full line) and CS (dotted line). Note that scales for Chrysophyceae (d) are different in CM (left axis) and CS (right axis).

plankton data, showing a clear separation between $\mathrm{CM}$ and CS samples (Fig. 6a). RDA axis $1\left(\lambda_{1}=0.20\right)$ and axis $2\left(\lambda_{2}=0.05\right)$ were both significant $(p<0.05)$ and explained $83.2 \%$ of the cumulative variance in the species-environment relationship and $29.4 \%$ of the total species variance. Partial RDA showed that water ionic content alone (represented by EC, DIC, DRSi) explained $13.4 \%$ of the total variability in phytoplankton data that could not be explained by $\mathrm{N}^{2}$. In a similar manner, the effects of different thermal stratification between lakes (represented by $\mathrm{N}^{2}$ ) determined $5.7 \%$ of the total variability in the species data. Out of the four explanatory environmental variables, $\mathrm{N}^{2}$ had the strongest relationship with the first axis $\left(\lambda_{1} / \lambda_{2}=0.15\right)$. Intersect correlations between environmental variables and the RDA axes indicated a primary axis of decreasing ionic concentration and increasing buoyancy frequency, where CM samples (on the left) are separated from CS samples (on the right) (Fig. 6a). In the lower right quadrant, four samples collected in CM in summer (JuneAugust) 2005 and 2006 are separated from the others. In the upper left quadrant, three CM samples (April, October and December 2005) are grouped with samples collected in CS in winter-early spring.

Figure $6 \mathrm{~b}$ shows the distribution of phytoplankton taxa, which provides evidence of two distinct algal assemblages. The highest number of taxa, most of them found exclusively in CS, lies in the right quadrants. On the left side of the plot, there is a group mainly composed of flagellates, both Cryptophyceae ( $P$. nannoplanctica and C. erosa) and Chrysophyceae (Mallomo- nas spp., Mallomonas akrokomos, Epipyxis sp., Pseudokephyrion entzii). Chlorococcales (e.g. Monoraphidium contortum, Pediastrum duplex, Planctonema lauterbornii, Scenedesmus acuminatus v. tetradesmoides and Scenedesmus linearis, all in the lower quadrant) and pennate diatoms (Cylindrotheca sp., Eunotia sp.1, Gyrosigma acuminatum, Navicula spp. and Nitzschia acicularis), together with the cyanophyte Synechocystis sp., were placed in the same cluster.

\section{DISCUSSION}

Differences in thermal stratification were assumed to be a result of the artificial mixing caused by dredging in $\mathrm{CM}$, but not in CS, since the two lakes are less than two kilometres apart and thus have similar morphology and are subject to the same meteorological conditions. According to other studies, differences in stratification regimes can explain both hydrochemical and biological variations among lakes (Lindenschmidt \& Chorus 1997; Judd et al. 2005). Sand dredging in CM caused sediment resuspension with a possible delivery of porewater nutrients and ions into the water column, explaining the highest values of EC, DIC and DRSI evidenced in the RDA. The conductivity reduction (ranging from 40 to $100 \mu \mathrm{S} \mathrm{cm}^{-1}$ ) measured in summer corresponded to an average decrease of $\mathrm{Ca}^{2+}$ and $\mathrm{HCO}_{3}{ }^{-}$and can be explained by calcium carbonate precipitation in both $\mathrm{CM}$ and CS.

In CS, where sand extraction has ceased, sediment resuspension is assumed to be negligible and biogeochemical processes in the water column and in the 

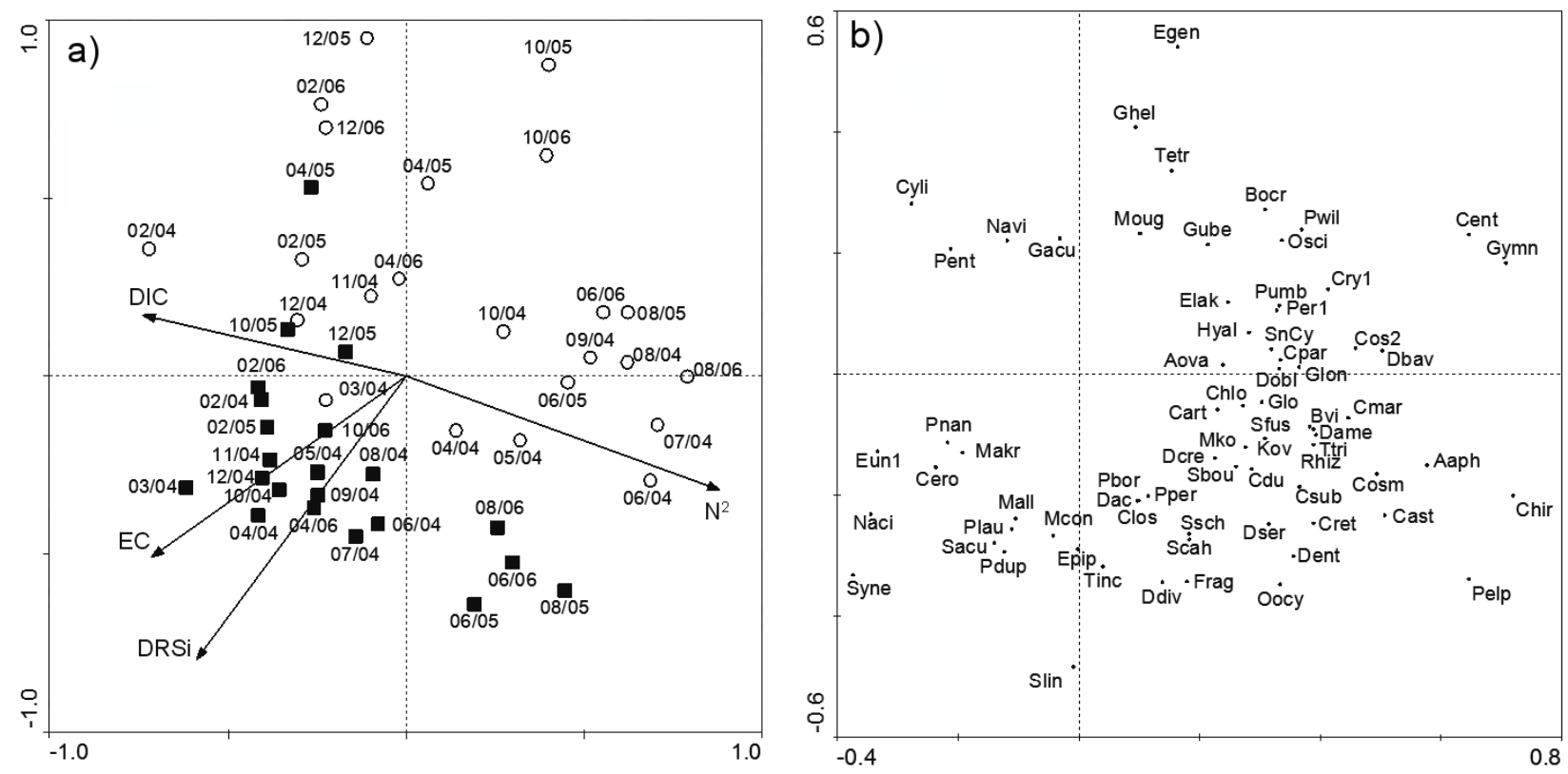

Fig. 6. (a) RDA ordination of the phytoplankton samples in CS (white circle) and CM (black square) and associated physical and chemical variables. Sampling date (mm/yy) is reported for each sample. (b) Scatter plot of phytoplankton taxa. Only taxa with fit range $>5 \%$ (72 on 93 taxa) are shown. Aaph: Aphanizomenon spp., Aova: Amphora ovalis, Bocr: Bitrichia ochridana, Bvit: Brachysira vitrea, Cart: Carteria spp., Cast: Coelastrum astroideum, Cdub: Coelosphaerium dubium, Cent: Centric diatoms, Cero: Cryptomonas erosa - C. erosa v. reflexa, Chir: Ceratium hirundinella, Chlo1: Unidentified Chlorococcales sp. 1 (19 $\mu \mathrm{m} \emptyset)$, Clos: Closterium acutum v. variabile, Cos2: Cosmarium cf. pygmaeum, Cosm: Cosmarium cf. leave, Cpar: Chrysochromulina parva, Cret: Coelastrum reticulatum, Cry1: Cryptomonas sp. 1, Cmar: Cryptomonas marsonnii, Csub: Cosmarium subcrenatum, Cylin: Cylindrotheca sp., Dacu: Diplopsalis acuta, Dame: Dinobryon sociale v. americana, Dbav: Dinobryon bavaricum, Dcre: Dinobryon crenulatum, Ddiv: Dinobryon divergens, Dent: Denticula sp., Dobl: Diploneis oblongella, Dser: Dinobryon sertularia, Egen: Euglena genicolata, Elak: Elakatothrix gelatinosa, Epip: Epipyxis sp., Eun1: Eunotia sp. 1, Frag: Fragilaria sp. 1, Gacu: Gyrosigma cf. acuminatum, Ghel: Gymnodinium helveticum, Gloe: Gloeocystis sp., Glong: Golenkiniopsis longispina, Gube: Gymnodinium cf. uberrimum, Gymn: Gymnodinium spp., Hyal: Hyaloraphidium contortum v. tenuissimum, Kova: Katablepharis ovalis, Makr: Mallomonas akrokomos, Mall: Mallomonas spp., Mcon: Monoraphidium contortum, Mkom: Monoraphidium komarkovae, Moug: Mougeotia spp., Naci: Nitzschia acicularis, Navi: Navicula spp., Oocy: Oocystis spp., Oscil: Oscillatoria spp., Pbory: Pediastrum boryanum, Pdup: Pediastrum duplex, Pelp: Peridiniopsis elpatiewskyi, Pent: Pseudokephyrion entzii, Per1: Peridinium sp. 1, Plau: Planctonema lauterbornii, Pnan: Plagioselmis nannoplanctica, Pper: Peridiniopsis penardiforme, Pumb: Peridinium umbonatum, Pwil: Peridinium willei, Rhizo: Rhizosolenia sp. , Sacu: Scenedesmus acuminatus v. tetradesmoides, Sbou: Spiniferomonas bourrellyi, Scah: Staurastrum cf. chaetoceras, Sfus: Siderocystopsis fusca, Slin: Scenedesmus linearis, SnCy: Snowella atomus Cyanogranis ferruginea, Ssch: Sphaerocystis schroeteri, Syne: Synechocystis sp., Tetr: Tetraselmis cordiformis, Tinc: Tetrachlorella incerta, Ttri: Tetrastrum triangolare.

sediment are probably the main processes controlling solute dynamics. The water in both lakes was rich in nitrate, which is likely due to agricultural runoff from heavily exploited farmland in the surrounding area (Giuliano 1995). In the older lake, CS, which had lower nitrate concentrations than $\mathrm{CM}$, the progressive nitrate decay was probably due to the development of biogeochemical processes (e.g., microbial denitrification) and uptake by autotrophic organisms, as has already been reported in mature lakes with similar origins in the same area (Bartoli \& Viaroli 2006). In CS, oxygen-consuming sedimentary processes also sustained rising $\mathrm{NH}_{4}{ }^{+}$ recycling in the deeper hypolimnion. In both lakes, the concentration of soluble reactive phosphorus was very low, close to the detection limit of the analytical method. Phosphorus accumulation in the hypolimnion was never measured despite summer anoxia. It is likely that excess phosphorus in these aquatic environments is efficiently trapped in the sediments through adsorption in clay minerals or precipitation as hydrohyapatite, as already observed in carbonatic environments (Minzoni \& Moroni 1987; Golterman 1995)

Multivariate analyses showed that different water column stability influenced phytoplankton distribution in the studied lakes, as previously reported for other lentic water bodies (Viner 1985; Salmaso 1996). Differences between phytoplankton communities in $\mathrm{CM}$ and CS were less evident in winter, when constant lower temperatures occurred through the water column and poor light penetration limited algal biomass in both lakes. Under these circumstances, a certain similarity in species assemblage and total biomass was observed in the lakes, as demonstrated by the overlap between CS samples and samples collected in CM from October to April in the upper left quadrant of RDA. Later on, differences in algal assemblages became more evident. The RDA analysis showed that some groups - such as chlorophytes, large pennates and cryptophytes - 
appeared to be better adapted to CM. Dredging induced water mixing that favoured the presence in the water column of large forms like colonial chlorophytes (i.e. Pediastrum duplex) and pennate diatoms (seemingly resuspended from sediments), which would quickly sink in a stratified lake due to their size and form. The action of the dredge also increased the depth of the mixing layers, leading to high values of $z_{\text {mix }} / z_{\text {eu }}$ and subjecting phytoplankton species to a high frequency of daytime light-dark alternations.

In $\mathrm{CM}$, artificial mixing gave a competitive advantage to taxa, such as cryptophytes, that generally grow and reproduce at low light intensities (Steward \& Wetzel 1986). The phytoplankton community of CM was occasionally dominated by chlorophytes, i.e., Tetrachlorella incerta, which is known to be a typical sand-pit species (Hindák \& Hindáková 2003), and Planctonema lauterbonii. The latter species has been associated with strong mixing events, probably due to its good "light-antenna" properties (Barlow 1984; Leitão et al. 2003). In summer 2006 and summer 2007 (Tavernini, unpublished data), chlorophytes were also represented by Closterium acutum v. variabile, which is known to be tolerant to mixing (Barone \& NaselliFlores 1994). Although transparency in both CM and CS was correlated with chlorophyll- $a$ during the study years, the concentration of suspended solids in the hypolimnion was higher in CM than in CS, inducing a different light climate in the deepest part of the lake. The success of $P$. lauterbornii and Closterium populations can be assumed to be an indicator of the selection of R-strategists (mixing-tolerant species) in turbid environments, as also reported by Barone \& Naselli-Flores (1994).

Once strong thermal stratification developed in CS, diatoms and flagellates (dino- and chrysophytes) became the most important species. Bacillariophyceae were mainly represented by small centric diatoms (e.g., Cyclotella spp. and Stephanodiscus parvus), which appear to tolerate stratification, probably because of their reduced sinking rates. As was also evidenced in the RDA, where CS samples were distributed along a gradient of decreasing DRSi, silica concentrations in CS declined due to sedimentation losses and incorporation into growing diatoms. This pattern was not evident in $\mathrm{CM}$, where sediment resuspension could also have provided a continuous supply of silica from sediments to the water column. However, silica concentrations were not found to be limiting diatom growth in either lake (Lindenschmidt \& Chorus 1997).

Although dinoflagellates were present in both lakes, they were more abundant in CS. Thermal stratification occurring in summer-early autumn favoured large, active moving species like Ceratium hirudinella and Gymnodinium spp., which were able to satisfy their requirements for energy and resources via vertical displacement through the water column.
The diatom-chrysophyte assemblage dominant in CS is characteristic of mesotrophic lakes with high alkalinity. In CS, taxa typical of meso-eutrophic waters have been found, e.g. Siderocystopsis fusca, Tetrastrum triangulare, Kirchneriella subcapitata and Crucigenia tetrapedia (Komarek \& Fott 1983). Species of the genus Oscillatoria, which typically inhabit the metalimnion of mesotrophic, stratified lakes (Reynolds et al. 2002), were also exclusively found in CS from June to October. Considering their annual average biovolumes and chlorophyll- $a$ values, CS can be classified as mesotrophic and $\mathrm{CM}$ as oligo-mesotrophic (Vollenweider \& Kerekes 1982; Rott 1984). The long water residence time typical of lakes with no surficial connections can increase nutrient accumulation and promote phytoplankton growth, particularly in water bodies affected by anthropogenic nutrients, e.g., from agriculture and sewage (Burford \& O'Donohue 2006). However, the absence of mixing can limit algal devlopment by reducing nutrient resuspension in the water column, as observed in 2006 in CS.

Unlike biomass, the number of phytoplankton taxa showed no significant differences between lakes, despite previous studies demonstrating that species richness increases with the age of the lake (Olding et al. 2000). However, the highest values of Margalef index were measured in 2005 and 2006, demonstrating that both $\mathrm{CM}$ and CS had unsaturated communities that were constantly subjected to invasion processes. Due to their spatial proximity, the two lakes shared more than $50 \%$ of the total phytoplankton taxa found in the study area. Although the Simpson evenness index showed a wide range of variation in both lakes, the highest values were measured in CM, where more species appeared to be able to coexist at a similar density. To date, we do not have sufficient information about the intensity of disturbance to prove our hypothesis, but the disturbance caused by hydraulic dredging could have prevented a few species from dominating exclusively and may have resulted in an increase in algal diversity (Reynolds 1984; Reynolds et al. 1993).

The role of zooplankton in shaping phytoplankton communities is well known. However, the presence of resuspended sediment particles in the water column may limit the ingestion rate of algal cells by filter feeders (especially cladocerans), reducing zooplankton survivorship and fecundity (see Kirk \& Gilbert 1990 and references therein). The filtering activity of herbivorous zooplankton could therefore be limited in pit-lakes, based on what was observed in this study, where multivariate analysis excluded the possibility that zooplankton had a major impact on phytoplankton community structure. Nevertheless, in CS, at the end of the excavation period, a progressive decline in total zooplankton density contrasted with an increase in large-size cladoceran abundance (Tavernini et al. 2009). In undisturbed conditions, cladocerans are thought to be better 
competitors than other zooplankters due to their higher feeding rates (Kirk 1991). For this reason, we cannot completely exclude the possibility that grazing, together with the abatement of nutrients in the water column, could also have contributed to the reduction in phytoplankton biomass observed in CS in the last sampling year.

During the excavation period, the action of dredging resulted in variations in thermal stratification and nutrient and ionic concentrations through the water column. These effects of artificial mixing significantly affect the phytoplankton communities of pit-lakes in terms of biomass and species composition. Unlike previous studies, our study showed that the age of the water bodies did not appear to influence species richness. However, the difference in the ages of the studied lakes may be too small for significant variations to be detected. On the whole, both sites present a high number of species, evidencing the role of these artificial water bodies as biodiversity hotspots in highly anthropized areas. Nevertheless, the reduction in Simpson index values measured in CS since December 2004 and the rapid increase in cyanobacteria numbers in this lake seem to indicate that these aquatic environments may evolve towards eutrophic conditions over a longer time period than that covered by this study, as has previously been reported by other authors (e.g., Hindák \& Hindáková 2003). For this reason, the excavation of pitlakes must be carried out following ecological criteria, e.g., shaping the basin morphology so as to minimize the volume of water that undergoes hypoxic or anoxic conditions.

\section{ACKNOWLEDGEMENTS}

Pierisa Panzani (CNR - ISE Pallanza) is gratefully acknowledged for her help in identifying phytoplankton. Aldo Marchetto and Alessandro Oggioni (CNR - ISE Pallanza) assisted with SEM analysis. Giuseppe Morabito (CNR - ISE Pallanza) gave helpful comments on an earlier version of the MS. Charles Nicholas Murray kindly revised the English language. Emanuele Emani and Claudio Bassanetti supported the organisation of this study, and financial support was provided by Bassanetti s.r.l. (Monticelli d'Ongina, Piacenza), Caripe s.r.l. (Mortizza, Piacenza) and Edilsuolo S.p.A. (Cremona).

\section{REFERENCES}

Agbeti, M.D., J.C. Kingston, J.P. Smol \& C. Watters. 1997. Comparison of phytoplankton succession in two lakes of different mixing regimes. Arch. Hydrobiol., 140: 37-69.

Alvarez-Cobelas, M., A. Baltanás, J.L. Velasco \& C. Rojo. 2006. Zooplankton dynamics during autumn circulation in a small, wind-sheltered, Mediterranean lake. Mar. Freshwater Res., 57: 441-452.

Anagnostidis, K. \& J. Komarek. 2005. Cyanoprokariota. Teil 2: Oscillatoriales. Sübwasserflora von Mitteleuropa. Gustav Fischer Verlag, Berlin: 759 pp.
A.P.H.A. 1998. Standard Methods for the Examination of Water and Wastewater. $20^{\text {th }}$ ed. American Public Health Association, Washington DC: $1220 \mathrm{pp}$.

Asencio, A.D. \& M. Aboal. 2000. Algae from La Serreta cave (Murcia, SE Spain) and their environmental conditions. Algol. Stud., 96: 59-78.

Barlow, R.G. 1984. Physiological responses of phytoplankton to turbulence and stable environments in an upwelling region. J. Plankton Res., 6: 385-397.

Barone, R. \& L. Naselli-Flores. 1994. Phytoplankton dynamics in a shallow, hypertrophic reservoir (Lake Arancio, Sicily). Hydrobiologia, 289: 199-214.

Bartoli, M \& P. Viaroli. 2006. Zone umide perifluviali: processi biogeochimici, funzioni ecologiche, problemi di gestione e conservazione. Biologia Ambientale, 20: 43-54.

Bourelly, P. 1981. Les algues d'eau douce. Initiation à la systématique. Tome II. Algues jaunes et brunes. Éditions Boubée \& Cie, Paris: 517 pp.

Bourelly, P. 1985. Les algues d'eau douce. Initiation à la systématique. Tome III. Les Algues bleus et rouges. Éditions Boubée \& Cie, Paris: 606 pp.

Bourelly, P. 1990. Les algues d'eau douce. Initiation à la systématique. Tome I. Les Algues Vertes. Éditions Boubée \& Cie, Paris: 572 pp.

Burford, M.A. \& M.J. O'Donohue. 2006. A comparison of phytoplankton community assemblages in artificially and naturally mixed subtropical water reservoirs. Freshwat. Biol., 51: 973-982.

Ejsmont-Karabin, J. 1995. Rotifer occurrence in relation to age, depth and trophic state of quarry lakes. Hydrobiologia, 313 /314: 21-28.

Fott, B. 1972. Chlorophyceae, Ord. Tetrasporales. Vol. 6. E. Schweizerbart'sche Verlagsbuchhandlung, Stuttgart: $116 \mathrm{pp}$.

Førster, K. 1982. Conjugatophyceae. Zygnematales und Desmidiales (excl. Zygnemataceae). Vol. 8. E. Schweizerbartsche Verlagsbuchhandlung, Stuttgart: 543 pp.

Garnier, J. \& G. Billen. 1994. Ecological interactions in a shallow sand-pit lake (Lake Créteil, Parisian Basin, France): a modelling approach. Hydrobiologia, 275/276: 97-114.

Genoni, P., F. Brunetti, S. Bertoletti, S. Comparoni \& L. Garibaldi. 2003. Strategie ecologiche del cianobatterio Planktothrix (Oscillatoria) agardhii/rubescens in laghi di cava soggetti ad eutrofizzazione. Seminario di Studi "Nuovi orizzonti dell'ecologia". Prov. Aut. Trento, ARPA Trento, C.I.S.B.A., Trento, 237-242.

Giuliano, G. 1995. Ground water in the Po basin: some problem relating to its use and protection. Sci. Total Environ., 171: 17-27.

Golterman, H.L. 1995. The labyrinth of nutrient cycles and buffers in wetlands: results based on research in the Camargue (southern France). Hydrobiologia, 315: 39-58.

Hillebrand, H., C.D. Dürselen, D. Kirschtel, U. Pollingher \& T. Zohary. 1999. Biovolume calculation for pelagic and benthic microalgae. J. Phycol., 35: 403-424.

Hindák, F. \& A. Hindáková. 2003. Diversity of cyanobacteria and algae of urban gravel pit lakes in Bratislava, Slovakia: a survey. Hydrobiologia, 506-509: 155-162.

Huber-Pestalozzi, G. 1961. Chlorophyceen, ord. Volvocales. Vol 5. E. Schweizerbart'sche Verlagsbuchhandlung, Stuttgart: $744 \mathrm{pp}$.

Huber-Pestalozzi, G. 1969. Euglenophyceen. Vol 4. E. Schweizerbart'sche Verlagsbuchhandlung, Stuttgart: 606 pp.

Huber-Pestalozzi, G. \& B. Fott. 1968. Cryptophyceae, Chloromonadophyceae, Dinophyceae. Vol 3. E. Schweizerbart'sche Verlagsbuchhandlung, Stuttgart: 322 pp.

Judd, K.E., H.E. Adams, N.S. Bosch, J.M. Kostrzewski, C.E. Scott, B.M. Schultz, D.H. Wang \& G.W. Kling. 2005. A case history: effects of mixing regime on nutrient dynamics and community structure in Third Sister Lake, 
Michigan during late winter and early spring 2003. Lake Reserv. Manage., 21: 316-329.

Kirk, K.L. \& J.J. Gilbert. 1990. Suspended clay and the population dynamics of planktonic rotifers and cladocerans. Ecology, 71: 1741-1755.

Kirk, K.L. 1991. Inorganic particles alter competition in grazing plankton: the role of selective feeding. Ecology, 72: 915-923

Komárek, J. \& K. Anagnostidis. 1999. Cyanoprokariota. Teil 1: Chroococcales. Sübwasserflora von Mitteleuropa. Spektrum Akademischer Verlag, Heildelberg, Berlin: 548 pp.

Komárek, J. \& K. Anagnostidis. 2005. Cyanoprokariota. Teil 2: 2nd Part: Oscillatoriales. Sübwasserflora von Mitteleuropa. Spektrum Akademischer Verlag, Heildelberg, Berlin: $759 \mathrm{pp}$.

Komarek, J. \& B. Fott. 1983. Chlorophyceae, ord. Chlorococcales. Das phytoplankton des Süsswasser: Systematik und Biologie. E. Schweizerbart'sche Verlagsbuchhandlung, Stuttgart: 1044 pp.

Krammer, K. \& H. Lange-Bertalot. 1991a. Bacillariophyceae 3. Teil: Centrales, Fragilariaceae, Eunotiaceae. Subwasserflora von Mitteleuropa. Spektrum Akademischer Verlag, Berlin: 598 pp.

Krammer, K. \& H. Lange-Bertalot. 1991b. Bacillariophyceae 4. Teil: Achnanthaceae, kritische ergänzungen zu Navicula (Lineolate) und Gomphonema. Subwasserflora von Mitteleuropa. Gustav Fischer Verlag, Stuttgart: 437 pp.

Krammer, K. \& H. Lange-Bertalot. 1997a. Bacillariophyceae 1. Teil: Naviculaceae. Subwasserflora von Mitteleuropa. Spektrum Akademischer Verlag, Berlin: 876 pp.

Krammer, K. \& H. Lange-Bertalot. 1997b. Bacillariophyceae 2. Teil: Bacillariaceae, Epithemiaceae, Surirellaceae. Sußwasserflora von Mitteleuropa. Spektrum Akademischer Verlag, Berlin: 610 pp.

Leitão, M., S.M. Morata, S. Rodriguez \& J.P. Vergon. 2003. The effect of perturbations of phytoplankton assemblages in a deep reservoir (Vouglans, France). Hydrobiologia, 502: 73-83.

Lindenschmidt, K.-E. \& I. Chorus. 1997. The effect of aeration on stratification and phytoplankton population in Lake Tegel, Berlin. Arch. Hydrobiol., 139: 317-346.

Minzoni, F. \& A. Moroni 1987. Phosphorus balance of an experimental ricefield in the Po plain. Agric., Ecosyst. Environ., 18: 223-230.

Naselli-Flores, L. 2000. Phytoplankton assemblages in twentyone Sicilian reservoir: relationships between species composition and environmental factors. Hydrobiologia, 424: $1-11$.

Naselli-Flores, L. \& R. Barone. 2007. Pluriannual morphological variability of phytoplankton in a highly productive Mediterranean reservoir (Lake Arancio, Southwestern Sicily). Hydrobiologia, 578: 87-95.

Olding, D.D., J.A. Hellebust \& M.S.V. Douglas. 2000. Phytoplankton community composition in relation to water quality and water-body morphometry in urban lakes, reservoirs and ponds. Can. J. Fish. Aquat. Sci., 57: 21632174.

Popovskì, J. \& L.A. Pfiester. 1990. Dinophyceae. Süßwasserflora von Mitteleuropa. Gustav Fischer Verlag, Berlin: $272 \mathrm{pp}$

Reynolds, C.S. 1984. Phytoplankton periodicity: the interactions of form, function and environmental variability. Freshwat. Biol., 14: 111-142.

Reynolds, C.S. \& E.G. Bellinger. 1992. Patterns of abundance and dominance of the phytoplankton of Rostherne Mere,
England. Evidence from an 18-year data set. Aquat. Sci., 54: $10-36$

Reynolds, C.S., J. Padisák \& U. Sommer. 1993. Intermediate disturbance in the ecology of phytoplankton and the maintenance of species diversity: a synthesis. Hydrobiologia, 249: 183-188.

Reynolds, C.S., V. Huszar, C. Kruk, L. Naselli-Flores \& S. Melo. 2002. Towards a functional classification of the freshwater phytoplankton. J. Plankton Res., 24: 417-428.

Rojo, C. \& M. Alvarez Cobelas. 1992. Taxonomy and ecology of phytoplankton in a hypertrophic gravel-pit lake. I. Bluegreen algae. Arch. Protistenk., 142: 77-90.

Rojo, C. \& M. Alvarez-Cobelas. 1993. Taxonomy and ecology of phytoplankton in a hypertrophic, gravel-pit lake II: Cryptophyceae, Euglenophyceae, Dinophyceae. Nova Hedwigia, 57: 47-63.

Rojo, C. \& M. Alvarez Cobelas. 1994. Population dynamics of Limnothrix redekei, Oscillatoria lanceaeformis, Planktothrix agardhii and Pseudanabaena limnetica (cyanobacteria) in a shallow hypertrophic lake (Spain). Hydrobiologia, 275/276: 165-171.

Rott, E. 1981. Some results from phytoplankton counting intercalibrations. Schweiz. Z. Hydrol., 43: 34-62.

Rott, E. 1984. Phytoplankton as biological parameter for the trophic characterization of lakes. Verh. Internat. Verein. Limnol., 22: 1078-1085.

Salmaso, N., M. Manfrin \& P. Cordella. 1995. Struttura e dinamica della comunità fitoplanctonica in un piccolo lago di falda (Rubano, Padova). S.It.E. Atti, 16: 703-706.

Salmaso, N. 1996. Seasonal variation in the composition and the rate of change of the phytoplankton community in a deep subalpine lake (Lake Garda, Northern Italy). An application of nonmetric multidimensional scaling and cluster analysis. Hydrobiologia, 337: 49-68

Scheffer, M. 1998. Ecology of Shallow Lakes. Kluwer Academic Publishers, Netherlands: 394 pp.

Sokal, R.R. \& F.J. Rohlf. 1995. Biometry: the principles and practise of statistics in biological research. $3 \mathrm{rd}$ ed. W.H. Freeman \& Co., New York: 887 pp.

Steward, A.J. \& R.G. Wetzel. 1986. Cryptophytes and other microflagellates as couplers in planktonic community dynamics. Arch. Hydrobiol., 106: 1-19.

Tavernini, S., P. Viaroli \& G. Rossetti. 2009. Zooplankton community structure and inter-annual dynamics in two sand-pit lakes with different anthropogenic impact. Int. Rev. Hydrobiol., 94: 290-307.

Ter Braak, C.J.F. \& C. Prentice. 1998. A theory of gradient analysis. Adv. Ecol. Res., 18: 271-317.

Ter Braak, C.J.F. \& P. Šmilauer. 2002. CANOCO Reference Manual and CanoDraw for Windows User's Guide: Software for Canonical Community Ordination (version 4.5). Microcomputer Power, Ithaca: $352 \mathrm{pp}$.

Utermöhl, H. 1931. Neue Wege in der quantitativen Erfassung des Planktons. Verh. Internat. Verein. Limnol., 5: 567-596.

Viaroli, P., G. Rossetti \& E. Pedrelli, editors. 1996. Riverine wetlands of the Po Valley, Management of Mediterranean Wetlands. Ministerio de Medio Ambiente, Madrid.

Viaroli, P., I. Ferrari \& G. Rossetti. 2002. Long-term limnological research in a quarry lake of the Po River, Italy. Verh. Internat. Verein. Limnol., 28: 576-581.

Viner, A.B. 1985. Thermal stability and phytoplankton distribution. Hydrobiologia, 125: 47-69.

Vollenweider, R. A. \& J. Kerekes. 1982. Eutrophication of Waters, Monitoring, Assessment and Control. OECD, Paris: 154 pp. 